\title{
Biological Brother
}

National Cancer Institute

\section{Source}

National Cancer Institute. Biological Brother. NCI Thesaurus. Code C96570.

A male who shares with his sibling the genetic makeup inherited from one or both of their shared biological parents. 